\title{
CONTRIBUTION OF JEWISH MINORITY TO THE ECONOMIC DEVELOPMENT OF BACAU
}

\author{
Filipoaia Cristina-Iolanda \\ University of Bucharest, Simion Mehedinti Doctoral School, Nature and sustainable \\ development \\ filipoaiacristinaiolanda@yahoo.com \\ Deju Mihai \\ "Vasile Alecsandri" University of Bacău \\ mihai.deju@ub.ro
}

\begin{abstract}
During more than six centuries of existence, Bacău benefited both from the favourable socioeconomic and political context, and from the interrelationships with the other communities, from the harmonious combination of these two elements resulting both the growth and development of the locality and the position in the local and regional hierarchy. The main beneficiaries of the progress made were of course the inhabitants, the city representing a living environment for them, as well as the essential factor in the functional dynamics and in the urban landscape. Giving meaning to the past, we must recognize that each community that contributed to the development of Bacău has its own history, Bacău becoming the trustee of the communities 'history entirety, which in perfect communion with Romanians defined the complex identity of the locality. The Jewish community is no exception, whose collaboration with Romanians for over two centuries has contributed to increasing the economic level of development of the locality since the second half of the $18^{\text {th }}$ century.
\end{abstract}

\section{Keywords}

Community; Jews; economic development; industry; Bacău

\section{JEL Classification}

O10; O18; N93; N94

\section{Introduction}

Basic component of the national urban system, Bacău municipality has grown and developed permanently during more than six centuries of existence, evolution determined on the one hand by the favourable socio-economic and political context and, on the other hand, by all interrelationships with the other settlements, their intensity and frequency determining its position in the urban hierarchy at local and regional level. Except for external influences, the city was primarily a living environment for its inhabitants, the main beneficiaries of progress made, but also an essential factor in the functional dynamics and urban landscape. Knowing the history of a place means not only "giving meaning to the past but also mapping the identities of the people" who populated that place over time to trace their spatial-temporal becoming and symbolically engrave them on the map of universal culture (Șerban, 2013). Each community that contributed to the existence of Bacău has its own history, Bacău being in fact the communities' history entirety that in a process of perfect symbiosis with the Romanians defined the complex identity of the locality. Each community, with its own religion and way of being, with its own traditions, holidays 
and symbols, has expressed its vision of the world, of man and of relationships with peers in a specific language, which distinguishes it from the majority population, as well as from other communities (Cmeciu, 2015).

\section{Jewish minority's contribution}

An essential element of the urban space, the population was probably its most dynamic component, any qualitative and quantitative changes recorded at its level, reflecting directly on the urban landscape. The Jewish population also played an important role in the dynamics of Bacău population. If at the beginning of the $16^{\text {th }}$ century Poland was the safest country for Jews, the precipitating events of the late $16^{\text {th }}$ and early $17^{\text {th }}$ centuries and the increase of anti-Semitic manifestations made it possible for Jews from all over Europe to move to the northern Carpathians, including to the Romanian territory, respectively to the current area of Bacău municipality, where they settled. The relationships "with the local population determined a peaceful coexistence" (Boldur, 2016).

The documentary sources attesting to the settlement of the Jews in these lands go back into the mists of time until the beginning of the $18^{\text {th }}$ century. Documents have been preserved showing that in 1742 the ruler of Moldavia, Constantin Mavrocordat, granted the Jewish merchants Avram and Boroh of Hotin fortress the right to settle in Bacău. In 1763, Bacău name is associated with that of Rabbi Ischer Dov, the son of the late Rabbi Iehuda Leib, and a few years later, in January 1766, Mozes, the Jew from Bacău, is mentioned in documents. In the $18^{\text {th }}$ century, the rulers of Moldavia and many boyars facilitated the establishment of craftsmen and merchants in the places they owned on the one hand to populate the fairs ravaged by battles, on the other hand for the important source of income they represented for the royal and manorial treasury. The golden bull of the ruler Ioniță-Sandu Sturdza of July 23, 1829, strengthened the privileges of the burghers and aimed to "attract merchants and craftsmen of any kind", a fiscal document from 1803 stating that there were 58 Jews, heads of households, who paid taxes. The inventories made after the censuses were not only fiscal, but also allowed a relative assessment of the demographic change. The inventory of 1831 , redone in 1832, shows that out of the almost 3000 inhabitants of Bacău at that time, 519 were Jews, respectively 13,5\% of the population. 68 families lived on crafts and trade. At the end of the $19^{\text {th }}$ century, most of the Jews of Bacău were merchants and craftsmen or had occupations in the oil, forestry or textile industry. Marius Mircu describes in novels published in Tel Aviv, the life of the Jewish community of Bacău at the beginning of the $19^{\text {th }}$ century. "The Jews were renowned merchants and craftsmen: braziers, silversmiths, barbers, tailors, brick makers, boiler makers, shoemakers, fur hat makers, a butcher, a torchbearer, a hatter, a baker, a glassblower, a saddler, a dyer, a coppersmith, a stonemason, a carpenter, a weigher and several tailors (Mircu, 1988). This demonstrates the skill of the Jews, their mastery and mercantile spirit, as well as their involvement in the economic life of Bacău and in the economic progress of society. The proof is the fact that in 1815 the Jewish tailors founded a synagogue, "on Tavernelor Street, on the initiative of Moise Leib, Iancu's son" (Zaharia, Chiriacescu). The tailors' guild was one of the important guilds, as it appears from "Yivo-bleter", the work of I. Kara, vol. 45, 1975, p.96. From the "ledger" of this guild, it results its special status. It dealt with professional activity, the coexistence of craftsmen, the observance of religious precepts, as well as the ethical norms within the profession. "It was forbidden to practice the trade by tailors who were not part of the guild, or who came from other 
localities" (Kara, 1995). Gradually other guilds appeared, the most numerous being those of shoemakers, also with their own synagogue, of woodworkers, scribes, glassmakers, locksmiths, barrel makers and tinsmiths. In many cases, the profession has turned into a name, many being called Argintaru, Croitoru, Căciularu, Cojocaru, etc. Various statistics, including that of craftsmen made by N. Colescu in the last years of the $19^{\text {th }}$ century highlight the obvious role of Jews in commercial activity in the city and in its development. The 569 "merchants" carried out various and varied activities, among them the members of the Brill family standing out in the field of grain trade. Some had become owners of large barns (Mordehai Ber, Berl Malai, Pinhas Edelstein, Saie Cofler, and later the Jacobsohn, Isaac Avram brothers, and others). The remarkable figure of Moișe Klein, the merchant who came from Poland and became in a very short time the largest grain trader on Bacău - Piatra Street, stands out in this field. Buium, his son, was the owner of the large grain barns on the mill canal and of the water mill, which later became Filderman Mill. Another important barn owner was Aron Schuler, also known for his philanthropic activity, for example, the establishment of the hospital that was named "Mina and Aron Schuler". Some grain merchants even had "business cards", respectively postcards printed with their name and quality (for example Iacob Bercovici). In A.C.M.E.O.R. archives of Israel there is evidence of business correspondence between David Raisel of Bacău and the grain exporter Chrisoveloni of Brăila, from 1899.

The ironware trade contributed to the strong development of Bacău and the whole of Moldovia. In the work "Bacăul din trecut și de azi (Bacău from the past and today)" published in 1933, Grigore Grigorovici mentions the largest "ironware wholesaler in Moldovia" (Grigorovici, 1933), Faiviș Klein, whose company provided rails for railway construction. The Jews were also present in the trade in timber and construction materials, obviously extremely necessary for urban development. Many Jews had Eau de Cologne shops both in Bacău and in the county. To that end, for example, the Hirschenbein brothers supplied all the fairs of Bacău County and many cities of Moldovia.

The first bookshop in Bacău was founded in 1860 by Herman Margulies.

The leather trade and the establishment of the first leather factories are directly related to the names of the Leibu and Iosif Brill brothers. Many of the Jewish merchants traded in haberdashery, others owned inns, pubs or other food units or with articles necessary for peasant households (harnesses, bricks, etc.). The shops were lined up in Strada Mare, Leca street, the streets leading to Focșani, Piatra and Roman.

At the end of the $19^{\text {th }}$ century, over $20 \%$ of the Jewish population of Bacău worked in handmade workshops in the most various fields: silversmiths, dyers, furriers, nougat sellers, bakers, jewellers, butchers, modistes, hatters, masons, tinsmiths, painters, locksmiths, shoemakers, etc.A proof that the Jewish craftsmen were trying to keep up with the requirements of the time and diversify their profiles to meet the new needs is the emergence of new trades, which had not been mentioned in previous documents: watchmakers, umbrellas, confectioners. It is interesting that in the statistics of the time some professions do not appear, such as coachmen, stove makers, carmen, sieve makers. The latter carried out the selection operation of cereals and oilseeds and fully contributed to increasing the number of cereal growers and their level of wellbeing.The magazine "Egalitatea" showed in December 1915 issue that the large number of craftsmen and the need to defend their interests led to the establishment of the Various Craftsmen Union on April 24, 1881, an organization that had such a high level that in 1915 was recognized as a legal and juridical person.In 1885, craftsmen working in the field of construction set up a mutual aid association, "Aghidas Haboinim", which operated until the outbreak of World War II. 
Jewish craftsmen sought to introduce increasingly new and modern methods of production. For example, the typographer Margulies brought to Bacău in 1882 the first flatbed printing machine, which also used Hebrew letters. The typographer M. Habor did the same in 1883, then D. Rosenberg, I. Copel, A. Goldşmit and others. The concern for modernization also existed in the photographic workshops, which had been taking colour photographs since 1877-1878 in Segal and Max Agatstein workshops. Having at their disposal the raw materials existing in the area (cereals, cattle, wood, crude oil, etc.), from small craft workshops they have evolved through the perseverance of entrepreneurs to top units in those fields. The most representative development was registered in the industrial branch of tannery, leather and footwear. The first tanneries were founded by brothers Leibu and Iosif Brill, on Florilor Street on the bank of Bistrița. They brought the Hungarian Ioșca and the German Carol Lahman as foremen. The tannery was destroyed by floods, after which another was created on Lecca Street, then it was moved to Tăbăcarilor Street, on the right bank of Bistrița and operated until its nationalization in 1948. "Noticing the lack of a yuft type leather factory, Leibu and Iosif Brill brothers brought David Iuftaru to Bacău, who, in 1850 , founded a leather factory in the northern part of the city". The subsequent reforms favoured the evolution and development of this industrial branch. Thus, Samuel Filderman, who was originally a seller of peasant sandals, also set up a tannery in the north of the city, from which gradually developed the important modern industrial complex known as S. Filderman Enterprises. It was entered in the register of industrial companies in 1890. Filderman then bought a leather factory from Paul Kisten. In 1908, dr. H. Perlbergher also set up a leather factory in Bacău that produced black and coloured leather using chrome tanning for the first time in the country. The competition determined the immediate modernization of Filderman's factory, by bringing from abroad the specialists and the machines that were needed. In 1908 the two manufacturers joined forces and "founded the first chrome system fine leather factory in Romania and Bacău systematic tannery" (Zaharia, Chiriacescu). During World War I, Filderman factories were the only companies in the country that supplied the army with leather and sole, introducing boots, harness and fur items into the manufacture (Zaharia, Chiriacescu). On Fabricilor Street, together with the tanneries owned by Herman Abramovici, Zelțer, Grinberg, Weiss, the leather factories of L. Klein (of 1880) and H. Pfeferman (of 1885) developed.

The Jews of Bacău were also very active in the field of milling. Using cereals from the eastern part of the county, in the second half of the $19^{\text {th }}$ century, Brill Nemteanu founded the first systematic mill. In 1904 Herman Brociner founded the mill which was later taken over and modernized by Calmovici and Sons.

The development of the textile industry in Buhuși was competed against by the appearance of this industrial branch in Bacău as well. The oldest textile enterprise in Bacău was Singher Cloth Factory, founded in 1908, which from the peasant cloth it initially produced came to produce high quality fabrics. Gloria - Leon Grad Scarf and Ribbon Factory, founded in 1913, is part of the same field. It has become the most important factory in the country in this field. In 1907, S. Oringher founded a quilt and mattress factory. Leon and Moritz Cloth Factory was then established, in $1913 \mathrm{H}$. Schulemsohn Factory, and in 1915 S. Marcusohn Quilt Factory.

The wood industry, also favoured by the existence of the vast forest area in the county and by the rafting that was practiced on Bistrița and which was advantageous from this point of view in Bacău, benefited from the involvement of Jewish entrepreneurs, who set up plank factories (Ștrul Kendler) or sawmills (I. Fedler, respectively DZ Goldenberg and Sons) (Zaharia, Chiriacescu). 
The roots of the food industry were represented by brandy distillers. Zisu Focșaner and Dumitrache Florea set up a brandy factory in 1834, with foreign craftsmen brought from Galiția. In 1892, Ellenberger alcohol factory was recorded in Mărgineni - Bacău, later taken over by Blum - Făinaru. The first brewery in Bacău, established in 1867, was taken over in 1919 by Ozias Herșcovici. From 1884, the gaseous water factory of J. Ellenbogen also operated, and from 1900 that of Tecuceanu.

The metallurgical industry is represented by companies that operated both before and after World War I. Among them were Herșcu Șvarț Foundry, Moise Șvarț Iron Construction Enterprise and A. Davidovici and Sons Foundry, an enterprise founded in 1918, which developed a lot after World War I.

Also set up by the Jews were the candle factories established between $1892-1895$ by A. Herșcovici, I. Heclinger, respectively M. Faclior, Blum - Făinaru oil refinery from Mărgineni, which started operating in 1877, the brick factory of A. Moscovici, the soap factories founded by Daniil I. Daniil and Bercu Gros in 1892, respectively Ellenberger in 1919, respectively the chemical laundry of Iulius Ilovici established in 1910.

The number of Jewish workers in the textile industry, tanneries, mills, leather, and print houses gradually increased. Jews also actively contributed to credit and banking field. In 1912, "Speranța" bank was established in Bacău - the first Jewish financial institution. According to issue 20 of the newspaper Egalitatea of July 1912, it started its operations with a capital of 20 thousand lei. The banking institution was intended mainly for Jewish craftsmen, as a credit and economy company. The difficult period that followed the World War II and the establishment of communism in Romania made many of more than 18000 Jews existing in Bacău around 1950 choose to emigrate, and the Jewish community to decline sharply, reaching in 2011, according to the census, to only 40 people.

\section{Conclusions}

In conclusion, in the second half of the $19^{\text {th }}$ century "the first industrial enterprises appeared in Bacău and it is not an exaggeration to say that the Jews were pioneers in this field". Whether they were modest industrial units or top enterprises, they all contributed to an active economic life in Bacău, came to the aid of the population with the most diverse goods and created jobs.

"Jewish traders brought very useful behavioural traits to the economic sector: innovative spirit, concern not to lock themselves in a narrow sector, but to trade as many categories of goods as possible and use procedures that accelerate the rotation of their capital. Many of them would focus on import-export activity. And some, ..., have been able to invest their wealth in more evolved forms of industrial and banking capital" (Zaharia, Chiriacescu).

\section{References}

Boldur Dimitrie-Ovidiu (2016), Monumente istorice Băcăuane (Băcău Historical Monuments), Bacău, Iulian Antonescu Museum Complex

Cmeciu Doina (coord), (2015), Povești europene retrăite (Relived European stories), (2015), Bacău, Europe Direct Information Center

Grigorovici, Gr.,. (1933), Bacăul din trecut și de azi (Bacău from the past and today)

Kara I. (1995), Title: Obștea evreiască din ... Bacău (Jewish community from ... Bacău), Bucharest, Hasefer Publishing House 
Mircu M. (1988), Croitorul din Back (The Tailor from Back), Tel Aviv

Șerban, L. (2013), Bacău. Palimpseste urbane (Urban palimpsest), Bacău, Rovimed Publishers Publishing House

Zaharia, D., Chiriacescu Emilia, Industria lemnului(Wood industry), file 189

Zaharia, D., Chiriacescu Emilia, Industria pielăriei (Leather industry), file 93

Bacău State Archives, file 19/1866

Encyclopedic Dictionary of Judaica 